\title{
Community structure of the macroinfauna in the sediments below an intertidal mussel bed (Mytilus chilensis (Hupe)) of southern Chile
}

\author{
Estructura comunitaria de la macroinfauna en los sedimentos bajo un banco intermareal de \\ bivalvos (Mytilus chilensis (Hupe)) en el sur de Chile
}

CRISTIAN DUARTE*, EDUARDO JARAMILLO, HERALDO CONTRERAS \& LUIS FIGUEROA

Instituto de Zoología, Universidad Austral de Chile, Valdivia, Chile;

* e-mail for correspondence: cduarte@uach.cl

\begin{abstract}
The mytilid mussel Mytilus chilensis (Hupe) can form dense beds in sedimentary areas of the inland coast of the Nord-Patagonic archipelagos of the Chilean coast (ca. 40-43 $\mathrm{S}$ ). During the autumn of 2002, we collected replicated samples at five intertidal stations in Panitao (Golfo de Reloncaví) ordered along a transect parallel to the low tide level and extended from the center of the bank (stations one and two with 100 and ca. $25 \%$ of mussel cover, respectively) to the bare sediments of the intertidal (stations 3, 4 and 5, without mussels). The macroinfauna was numerically dominated by Polychaeta, Oligochaeta and Crustacea Peracarida. The total number of species collected was 14 , being the most abundant the polychaete Perinereis vallata, oligochaetes from the family Tubificidae and the crustacean amphipod Corophium insidiosum. The number of species, Shannon-Wiener diversity and total abundance of the macroinfauna did not differ significantly among stations. However, the percent contribution of polychaetes was significantly higher at the sediments sampled outside the mussel bed (stations three, four and five), while the percentual contribution of oligochaetes was significantly higher at the sediments sampled in the mussel bed (stations one and two). No significant differences were found between the percentual contribution of peracarid crustaceans between stations sampled in the mussel bed versus that sampled on the bare intertidal. The graphic results of NMMDS show that the macroinfaunal assemblage of the stations located inside the mussel bed differed from that of stations located outside the bed. Results of SIMPER and ANOSIM showed that the macroinfaunal composition of stations one and two was significantly dissimilar (61-54\%) to that of the stations located outside the mussel bed, which had similar composition. The graphic results of a NMMDS based upon sedimentological characteristics show that most replicates of station one and some of station two separate from that of the other stations (i.e. located outside the mussel bed). Results of ANOVA showed significant differences for all sediment variables, with the exception of percentages of gravel particles and mean grain size of sands. The most noticeable difference was that shown by station 1 (lower contents of sand and higher content of mud, biogenic aggregates and total organic matter). The results of BIO-ENV routine showed that the best fit between the taxonomic composition of the macroinfauna and single sediment variables, was reached with percentages of sand and mud. It is concluded, that mussel beds of sedimentary bottoms of southern Chile have a significant role on the sediment quality and community structure of the macroinfauna, a probable combined effect of physiological processes (ingestion of larvae, biodeposition) and the complex physical matrix of the bed.
\end{abstract}

Key words: mussel beds, Mytilus chilensis, macroinfauna, southern Chile.

\section{RESUMEN}

El bivalvo Mytilus chilensis (Hupe) puede formar densos bancos en áreas sedimentarias de la costa protegida de los archipiélagos norpatagónicos de la costa de Chile (ca. 40-43 $\mathrm{S}$ ). Durante el otoño del 2002, se recolectaron muestras replicadas en cinco estaciones en la zona intermareal de Panitao (Golfo de Reloncaví) a lo largo de un transecto paralelo a la línea de marea baja y extendido desde el centro de un banco de bivalvos (estaciones uno y dos con 100 y ca. $25 \%$ de cobertura, respectivamente) hasta una zona libre de bivalvos (estaciones tres, cuatro y cinco). La macroinfauna estuvo dominada numéricamente por los grupos Polychaeta, Olygochaeta y Crustacea Peracarida. El número total de especies recolectadas fue 14, siendo las más abundantes el poliqueto Perinereis vallata, oligoquetos de la familia Tubificidae y el crustáceo anfípodo Corophium insidiosum. El número de especies, el índice de diversidad de Shannon-Wiener y la abundancia total de la macroinfauna no presentaron diferencias significativas entre las estaciones de muestreo. Sin embargo, la contribución porcentual de los poliquetos fue significativamente más alta en los sedimentos fuera 
del banco de bivalvos (estaciones tres, cuatro y cinco), en tanto que la contribución porcentual de los oligoquetos fue significativamente más alta en los sedimentos muestreados dentro del banco (estaciones uno y dos). No se registraron diferencias significativas en la contribución porcentual de los crustáceos peracáridos entre las distintas estaciones de muestreo. Los resultados gráficos del análisis de escalamiento multidimensional no métrico, mostraron que el ensamble de la macroinfauna de las estaciones localizadas dentro del banco de bivalvos difirió de aquellas localizadas fuera del mismo. Los resultados de los análisis de SIMPER y ANOSIM mostraron que la composición de la macroinfauna de las estaciones uno y dos fue significativamente disimilar (61-54\%) a la de las estaciones ubicadas fuera del banco, cuyas composiciones faunísticas fueron similares. Los resultados gráficos del análisis de escalamiento multidimensional no métrico basado en las características sedimentológicas, mostraron que la mayoría de las réplicas de la estaciones uno y dos se separaron del resto de estaciones (i.e. aquellas localizadas fuera del banco). Los resultados del ANDEVA mostraron diferencias significativas para todas las variables sedimentológicas, excepto para el porcentaje de grava y tamaño medio de la partícula, observándose las diferencias más marcadas en la estación 1 (más bajos contenidos de arena y más altos contenidos de fango, agregados biogénicos y materia orgánica total). Los resultados de la rutina BIO-ENV, mostraron que el mejor ajuste entre la composición taxonómica de la macroinfauna y una variable sedimentológica, se alcanzó con el porcentaje de arena y fango. Se concluye, que los bancos de bivalvos de fondos sedimentarios del sur de Chile influyen significativamente sobre las características sedimentológicas y la estructura comunitaria de la macroinfauna, debido probablemente a un efecto combinado de procesos fisiológicos (ingestión de larvas, biodepositación) y la compleja matriz física del banco.

Palabras clave: bancos de choritos, Mytilus chilensis, macroinfauna, sur de Chile.

\section{INTRODUCTION}

Bivalve suspension feeders form dense, extensive and persistent beds on the intertidal zone all around the coasts of the world oceans (Suchanek 1985, Ragnarsson \& Rafaelli 1999, Commito \& Rusignuolo 2000, Commito \& Dankers 2001). Due to the fact that these organisms can change their physical and biological surroundings (e.g., Dame et al. 2001), mussels have been considered to be ecosystem engineers (Crooks 2002), playing an important role in structuring macrofaunal communities (e.g., Dame et al. 2000, Commito et al. 2005), either by excluding species or by facilitating the persistence of other ones (Commito \& Dankers 2001, Gutiérrez et al. 2003).

It has been shown that on intertidal rocky shores, mussel beds influence significantly the community structure of the whole assemblage, either by competing for primary substrate with other organisms, such as barnacles (e.g., Paine \& Levin 1981, Menge et al. 1994) or by creating secondary substrate for other organisms and thus, increasing local diversity (e.g., Suchanek 1980, Tsuchiya \& Nishihira 1985, 1986, Peake \& Quinn 1993). For the sedimentary intertidal, it has been shown that the macrofauna occurring in the underlying sediments of mussel beds show quite noticeable differences with that of nearby sediments lacking a mussel canopy (e.g., Commito 1987,
Commito \& Boncavage 1989, Ditmman 1990, Crooks 1998, Crooks \& Khim 1999, Ragnarsson \& Raffaelli 1999). Based on these considerations, Woodin (1976) hypothesized that adult-larval interactions were the mechanism involved in causing the differences in community structure of macroinfaunal assemblages located inside and outside the bivalve beds, predicting that no abundant macroinfauna should occur inside beds of suspension-feeder bivalves. Woodin's hypothesis was later modified by Commito (1987) and Commito \& Boncavage (1989), who argued that brooding species could reach high population abundances within beds. On the other hand, recent studies have shown that the complex physical structure originated by the mussel beds (which promotes depositation of fine particles and organic matter), can be another mechanism through which mussel beds influence patterns of the surrounding benthic organisms (e.g., Crooks 1998, Crooks \& Khim 1999).

The mytilid mussel Mytilus chilensis (Hupe) can form dense beds (up to 1,000-5,000 ind $\mathrm{m}^{-2}$ ) in sedimentary areas of the inland coast (i.e. not exposed to the breaking waves of Pacific Ocean) of the north Patagonic archipelagos of the Chilean coast (ca. 40-43 $\mathrm{S}$ ). No studies have been carried out to analyze the role of these mussel beds in the community structure of the macroinfauna occupying the underlying sediments, or evaluated differences with the 
macroinfauna inhabiting nearby bare sediments without mussel beds. Thus, the objectives of this study were to find answers to the following questions: (i) does the macroinfaunal assemblage, occurring in the sediments underneath a mussel bed, differ from that located outside that bed, in terms of species richness, diversity and population abundances?, (ii) if so, is there any difference in community attributes according to differences in percentage cover of mussels?, (iii) does the sediment characteristics underneath the mussel bed, differ from that of nearby bare sediments without mussels?, and (iv) is there any relationships between the macroinfauna and sediment characteristics? To answer these questions we compared the community structure of the macroinfauna inhabiting an intertidal sedimentary habitat of southern Chile under three scenarios: (1) sediments totally covered by a mussel bed (100\% cover), (2) sediments partially covered by mussels (ca. 25 $\%$ cover), and (3) bare sediments without mussels. We aim that this study will help to understand the effects of sedimentary bivalves on the surrounding biota. This is considered important because in this area of the Chilean coast Mytilus chilensis and other bivalves such as the razor clam Tagelus dombeii (Lamark) and several species of clams (Venus antiqua King \& Broderip, Semele solida (Gray) and Gari solida (Gray) are heavily exploited, probably cascading effects on the rest of the macroinfaunal assemblages.

\section{MATERIAL AND METHODS}

\section{The study area}

The mussel bed studied was located at the sedimentary intertidal of Panitao, Golfo de Reloncaví, south central Chile $\left(41^{\circ} 32^{\prime} \mathrm{S}\right.$; $\left.73^{\circ} 01^{\prime} \mathrm{W}\right)$. The study area is located on the northern area of the Nord-Patagonic archipelagos, the inland coast of Chile characterized by tidal ranges close to $5 \mathrm{~m}$ (Viviani 1979) (Fig. 1A).

\section{Collection and preliminary treatment of samples}

The sampling was carried out during spring low tides of May 2002. Replicated samples $(n=6)$ were collected at five stations ordered along a transect parallel to the low tide level and extended from the center of the bank to the bare sediments of the intertidal (i.e., without mussels). Station one was located at a point with $100 \%$ of mussel cover; station two was nearly at the edge of the bank (ca. $25 \%$ of mussel cover), station three was out of the very edge of the mussel bed, while stations four and five were 6 and $12 \mathrm{~m}$ apart from station three. The last three stations were on bare sands without mussels (Fig. 1B). Samples for macroinfaunal analyses were collected with a plastic cylinder $7.5 \mathrm{~cm}$ in diameter $\left(0.009 \mathrm{~m}^{2}\right)$ and buried to a depth of $15 \mathrm{~cm}$ into the sediment. The mat of mussels included in the sampled areas of stations one and two were carefully separated from the sediment below. A subsample of sediments for textural and granulometric analyses of sediments was collected with a plastic cylinder $2.5 \mathrm{~cm}$ in diameter and buried to a depth of $5 \mathrm{~cm}$ into the sediment. These samples were frozen $\left(-20^{\circ} \mathrm{C}\right)$ until further analyses (see below). Sediment samples for macroinfaunal analyses were sieved through a 1,000 microns sieve and the residue was preserved in $10 \%$ formalin until sorting and counting of organism in the laboratory.

\section{Laboratory analyses}

The residue stored in formaldehyde for macroinfaunal analyses was washed with tap water on a 500 micron sieve to eliminate excess of sediments and formaldehyde. Later on, the macroinfaunal organisms were sorted until the lowest taxonomic level.

Samples for textural and granulometric analysis were defrozen and wet sieved to separate the following fractions: gravel (particles > 2,000 $\mu \mathrm{m}$ ), sand (particles 63-2,000 $\mu \mathrm{m})$, mud (particles < $63 \mu \mathrm{m}$ ) and biogenic aggregates (Anderson et al. 1981). Mean grain size of sands (the dominant fraction in the sediments of each site) was calculated based upon fall velocity of particles (Emery 1938) and the moment's computational methods (Seward-Thompson \& Hails 1973). Total organic matter was estimated after calculations of weight differences between samples incinerated at $550{ }^{\circ} \mathrm{C}$ per $6 \mathrm{~h}$ and previously dried at $60{ }^{\circ} \mathrm{C}$ per $24 \mathrm{~h}$. 


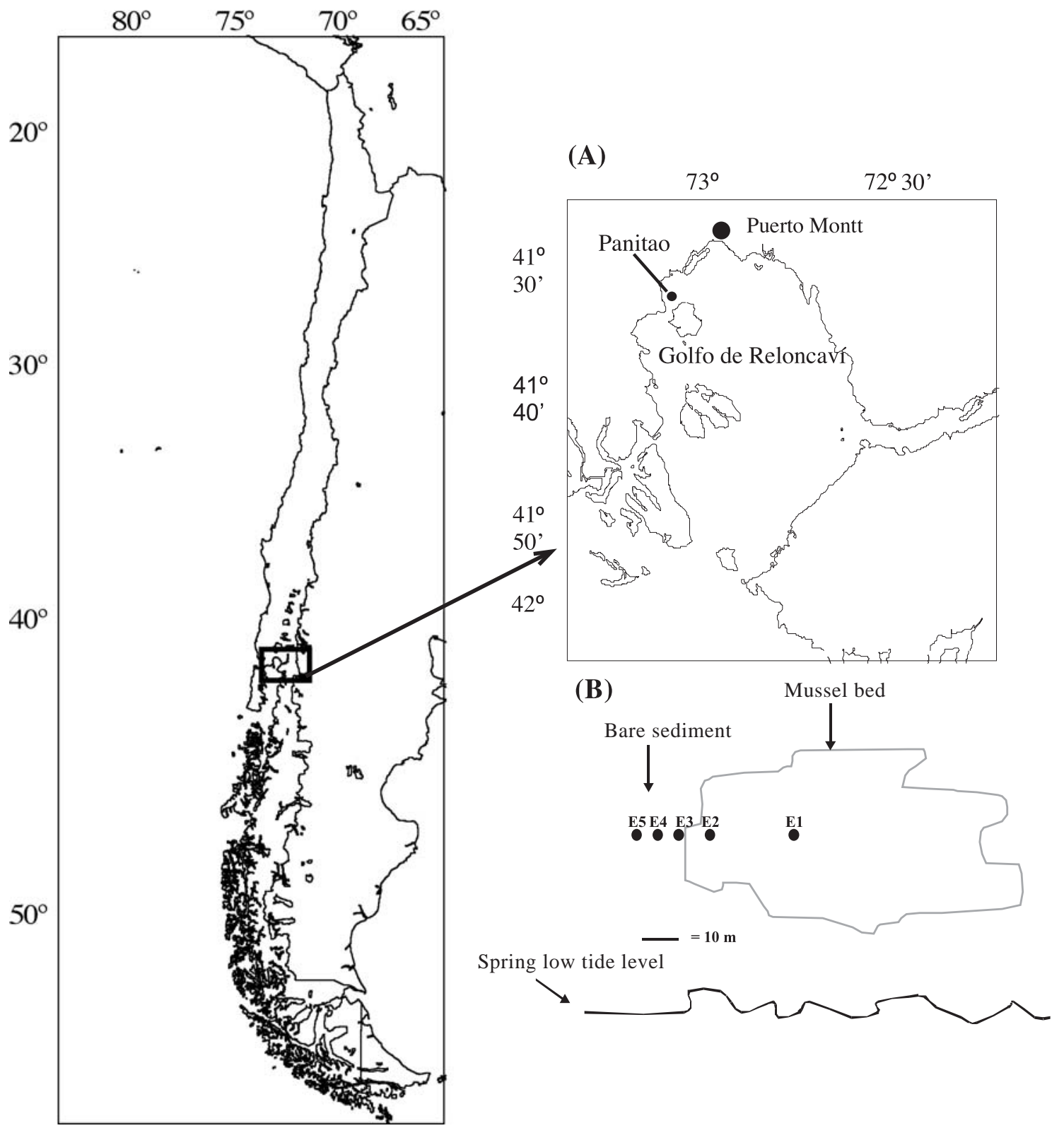

Fig. 1: (A) Location of the intertidal sedimentary site at Panitao on the coast of Golfo de Reloncaví, south central Chile. (B) Spatial distribution of the sampling stations at the study site: while stations one and two were on the mussel bed, station three was located right out of the edge of the bed and stations four and five were on sediments without mussels (see Material and Methods for details). The hatched area represents the location of the mussel bed with respect to the spring low tide level.

(A) Ubicación del sitio sedimentario intermareal en Panitao, costa del Golfo de Reloncaví, centro sur de Chile. (B) Distribución espacial de las estaciones de muestreo en el sitio de estudio: las estaciones uno y dos estuvieron en el banco de bivalvos, la dos inmediatamente fuera del borde del banco, a la vez que las estaciones cuatro y cinco se ubicaron en sedimentos sin bivalvos (ver Materiales y Métodos para detalles). El área achurada señala la ubicación del banco de bivalvos con respecto al nivel de marea baja de sicigia. 

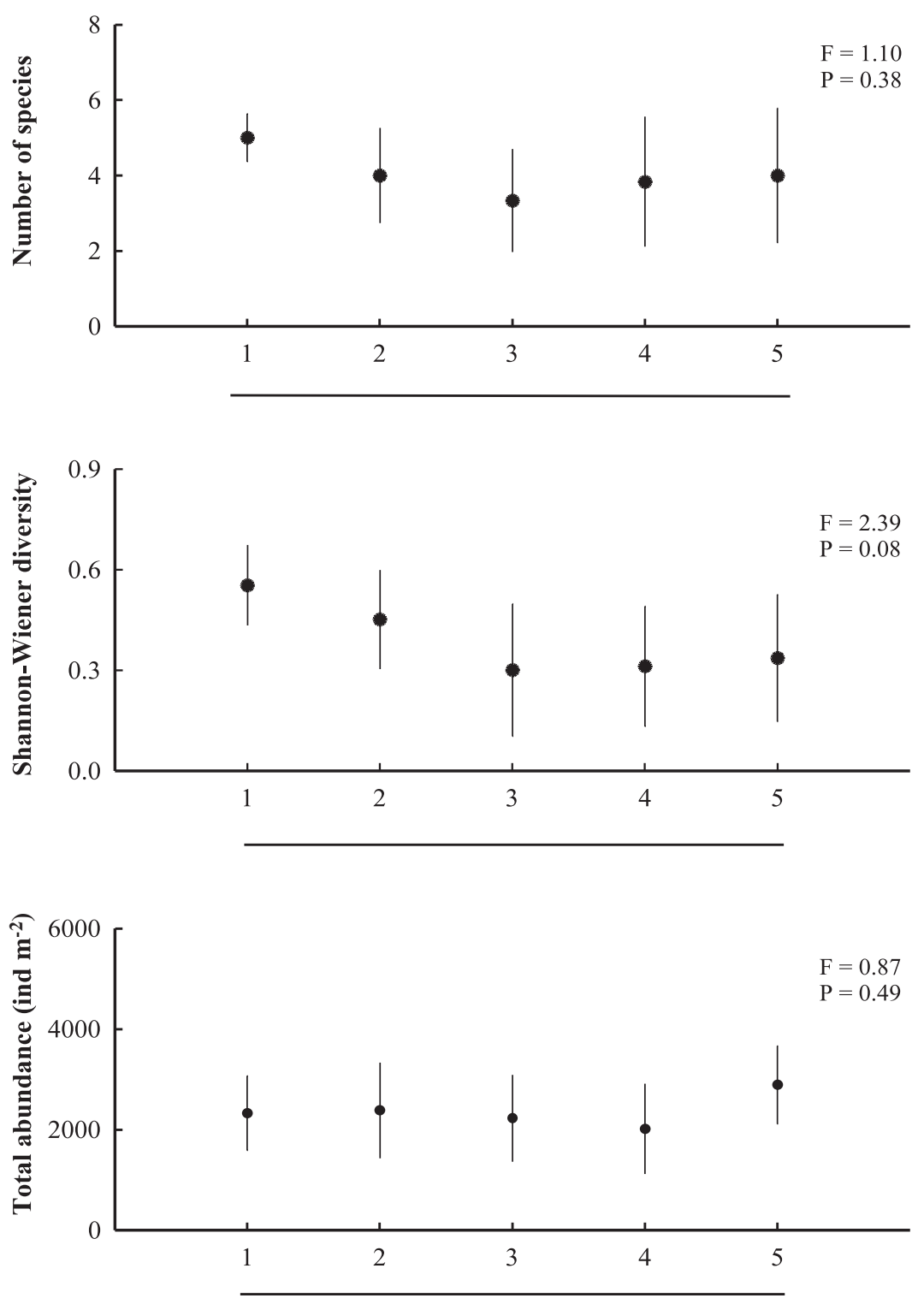

Sampling station

Fig. 2: Means ( \pm 1 standard deviation) of number of species, Shannon-Wiener diversity and total abundance of the macroinfauna at the sampling stations. Lines link means not significantly different among each others $(\mathrm{P}>0.05)$.

Promedios ( \pm 1 desviación estándar) del número de especies, diversidad de Shannon-Wiener y abundancia total de la macroinfauna en las estaciones de muestreo. Las líneas unen promedios que no difieren significativamente entre sí $(\mathrm{P}>0,05)$.

\section{Data analysis}

The Shannon-Wiener diversity index was calculated according to Brower \& Zar (1977). One way ANOVA (Sokal \& Rohlf 1995) was used to examine eventual differences among means of variables related to the structure of the macroinfauna (number of species, Shannon-
Wiener diversity and population abundances) and sediments (percentages of gravel, sand, mud, biogenic aggregates and total organic matter and mean grain size of sands). Macroinfaunal population abundances and percentages were transformed by $\log (n+1)$ and arcsin, respectively, to fulfil the basic assumptions of ANOVA (normality and 
homogeneity of variances tested through Kolmogorov-Smirnov and Bartlett's test, respectively) (Sokal \& Rohlf 1995). The aposteriori Tukey HSD test (honestly significant difference) (Sokal \& Rohlf 1995) was used to run comparison analyses among means. A probability value $<0.05$ was used to pinpoint significant differences among means.

Analysis of non metric multidimensional scaling (NMMDS) was carried out to explore similarity in fauna and sediment characteristics among stations. These ordination analyses were based upon a similarity matrix calculated trough the Bray-Curtis similarity coefficient with root transformation of the data and with normalised Euclidean distance, for fauna and sediment data, respectively (Clarke \& Warwick 1994). The routine ANOSIM (Clarke \& Warwick 1994) of the statistical package PRIMER was used to evaluate if significant differences were present among the fauna and sediment composition of sampling stations. Simple regression analyses (Sokal \& Rohlf 1995) and the routine BIO-ENV of PRIMER (see Clarke \& Ainsworth 1993), were used to explore which physical variables had a significant role in explaining the spatial variability of the macroinfauna. Physical variables were successively added to the predicted model BIO-ENV to improve the coefficient of correlations. To evaluate if any physical variables were collinear $(r>0.95)$, the Pearson correlation analysis was performed, before running the BIO-ENV routine.

\section{RESULTS}

\section{The macroinfauna assemblage}

The macroinfauna was numerically dominated by Polychaeta, Oligochaeta and Crustacea Peracarida. The total number of species $(n=30$ samples) collected in the study area was 14 . The most abundant species were the polychaete Perinereis vallata (Grube), oligochaetes of the family Tubificidae and the crustacean amphipod Corophium insidiosum Crawford, (Table 1). The most abundant species at station 1 were oligochaetes from the family Tubificidae, the polychaete $P$. vallata and the amphipod Hyale sp. with mean abundances of 891.5, 542.6 and 329.5 ind $\mathrm{m}^{-2}$, respectively (Table 1 ). The sediments of station 2 were dominated by tubificid oligochaetes (910.9 ind $\mathrm{m}^{-2}$ ) and by the polychaetes Boccardia sp. and P. vallata with mean abundances of 290.7 and 775.2 ind $\mathrm{m}^{-2}$, respectively. The most abundant species at stations 3, 4 and 5 were $P$. vallata with 1627.9 , 1589.1 and 1976.7 ind $\mathrm{m}^{-2}$, respectively and the amphipod $C$. insidiosum with 213.2, 135.7 and 562.0 ind $\mathrm{m}^{-2}$, respectively (Table 1 ).

Results of ANOVA showed that the number of species, Shannon-Wiener diversity and population abundances of the macroinfauna did not differ significantly $(\mathrm{P}>0.05)$ among stations (Fig. 2). Polychaetes and oligochaetes were represented by similar percentages at the sediments of stations one and two (42-47 versus $40 \%$ ), while the percentages of polychaetes was far higher than that of oligochaetes at the sediments of stations 3, 4 and 5 (77-86\% versus 1-3\%) (Fig. 3). Thus, the percentage of contribution of polychaetes was significantly higher $\left(\mathrm{F}_{4,25}=12.57, \mathrm{P}=0.001\right)$ at the sediments sampled outside the mussel bed (stations three, four and five) (Fig. 3), mainly due to the dominance of P. vallata (ca. $90 \%$ ) (Table 1). On the other hand, the percentage of contribution of oligochaetes was significantly higher $\left(\mathrm{F}_{4,25}=38.63, \mathrm{P}=0.001\right)$ at the sediments sampled on the mussel bed (stations one and two) (Fig. 3). No significant differences were found between the percent contribution of peracarid crustaceans $\left(\mathrm{F}_{4,25}=0.23, \mathrm{P}=0.92\right)$ between stations sampled in the mussel bed vs. that sampled on the bare intertidal (Fig. 3). Similar results are found when the population abundances of the most common species are compared; i.e. P. vallata and the tubificid oligochaete had in general, lower and higher population abundances respectively, at the stations located inside the mussel bed (stations 1 and 2), while the population abundances of $C$. insidiosum did not differ significantly $(\mathrm{P}>0.05)$ among stations (Fig. 4).

The graphic results of NMMDS show that the macroinfaunal assemblage of the stations located inside the mussel bed differed from that of stations located out of the bed (Fig. 5). The macroinfauna composition of stations one and two was about 61 and $54 \%$ dissimilar to that of the stations located outside the mussel bed (Table 2). While these percentages of dissimilarities were significantly different, no significant differences were found when stations sampled within each sector (mussel 
bed and bare intertidal) were compared (results of SIMPER and ANOSIM tests) (Table 2). The results of SIMPER also showed that the polychaete $P$. vallata and the tubificid oligochaete contributed with nearly $40 \%$ to the percentage dissimilarity between stations located inside versus outside the mussel bed.

\section{The sediments}

The percentages of gravel particles $(>2,000 \mu \mathrm{m})$ decreased steadily from station $1(\sim 6 \%)$ to stations 4 and 5 ( $\sim 5$ and $4 \%$ respectively) (Fig. 6, Table 3 ). Sand particles $(63-2,000 \mu \mathrm{m})$ were the most represented ones at the sampling stations; that sediments of stations one and two had lower percentages (65 and $83 \%$, respectively), as compared to that of stations three, four and five (87, 90 and $92 \%$, respectively) (Fig. 6, Table 3). Mean grain size of sands varied little among stations (nearly $400 \mu \mathrm{m}$ ) (Fig. 6). Mud particles (< $63 \mu \mathrm{m})$ decreased from station 1 and $2(\sim 24$ and 10 $\%$, respectively) to those located outside the mussel bed ( 6-2 \%) (Fig. 6, Table 3). Biogenic aggregates were higher at the sediments of station $1(\sim 4 \%)$ as compared to the other stations (0.5-1.0
\%) (Fig. 6, Table 3). Total organic matter was higher at the sediments of station $1(\sim 7 \%)$ as compared to the sediments of the other stations (< $5 \%)$. Results of ANOVA showed significant differences $(\mathrm{P}<0.05)$ for all variables, but percentages of gravel particles and mean grain size of sands, being the most noticeable difference that shown by station 1 . Its sediments had the lowest percentage of sand particles and the highest percentage of mud particles, biogenic aggregates and total organic matter (Fig. 6).

The graphic results of NMMDS show that most replicates of station 1 and some of station 2 separate from those of the other stations (i.e., located outside the mussel bed) (Fig. 7). Results of SIMPER and ANOSIM tests showed that the sedimentological composition of station one was around $8-13 \%$ significantly dissimilar to that of the other four stations (Table 4). On the other hand, the sediment characteristics of station two were around 4-7 \% significantly dissimilar to those of stations four and five, with no dissimilarity with station three. Station three was significantly dissimilar in sedimentological features with station five $(\sim 7 \%)$ and also station four with five $(5 \%)$ (Table 4$)$.

TABLE 1

Abundance of the macroinfaunal species (ind $\mathrm{m}^{-2}$ ) collected at the sampling stations. The values are means and standard deviations in parentheses

Abundancia de las especies de la macroinfauna (ind $\mathrm{m}^{-2}$ ) colectada en las estaciones de muestreo. Los valores son promedios con desviación estándar en paréntesis

\begin{tabular}{|c|c|c|c|c|c|}
\hline Taxon & Station 1 & Station 2 & Station 3 & Station 4 & Station 5 \\
\hline \multicolumn{6}{|l|}{ Polychaeta } \\
\hline Cirratulidae & $19.4(47.5)$ & $0(0)$ & $0(0)$ & $0(0)$ & $0(0)$ \\
\hline Boccardia sp. & $193.8(281.6)$ & $290.7(191.1)$ & $19.4(47.5)$ & $96.9(135.9)$ & $96.9(186.3)$ \\
\hline Perinereis vallata & $542.6(203.6)$ & $775.2(216.5)$ & $1,627.9(665.9)$ & $1,589.1(748.8)$ & $1,976.7(416.0)$ \\
\hline Capitella sp. & $213.2(298.0)$ & $19.38(47.47)$ & $0(0)$ & $0(0)$ & $38.8(60.0)$ \\
\hline Gliceridae & $38.8(60.0)$ & $0(0)$ & $19.4(47.5)$ & $0(0)$ & $0(0)$ \\
\hline Polydora sp. & $0(0)$ & $0(0)$ & $0(0)$ & $0(0)$ & $19.4(47.5)$ \\
\hline Leitoscoloplos sp. & $0(0)$ & $0(0)$ & $0(0)$ & $38.8(60.0)$ & $38.8(94.9)$ \\
\hline Lumbrinereis sp. & $0(0)$ & $0(0)$ & $0(0)$ & $19.4(47.5)$ & $0(0)$ \\
\hline \multicolumn{6}{|l|}{ Crustacea } \\
\hline Isocladus calcareus & $19.4(47.5)$ & $0(0)$ & $0(0)$ & $0(0)$ & $0(0)$ \\
\hline Hyale sp. & $329.5(378.0)$ & $174.4(373.2)$ & $96.9(135.9)$ & $38.8(60.0)$ & $38.8(60.0)$ \\
\hline Corophium insidiosum & $77.5(140.8)$ & $174.4(142.4)$ & $213.2(171.2)$ & $135.7(114.3)$ & $562.0(461.7)$ \\
\hline Exosphaeroma lanceolata & $0(0)$ & $0(0)$ & $135.7(237.4)$ & $58.1(97.3)$ & $38.8(60.0)$ \\
\hline \multicolumn{6}{|l|}{ Oligochaeta } \\
\hline Tubificidae & $891.5(317.7)$ & $910.9(259.1)$ & $77.5(189.9)$ & $19.4(47.5)$ & $58.1(63.7)$ \\
\hline Nemertea & $0(0)$ & $38.8(94.9)$ & $38.8(94.9)$ & $19.4(47.5)$ & $19.4(47.5)$ \\
\hline Total & $2,325.6(742.7)$ & $2,383.7(949.7)$ & $2,228.7(865.2)$ & $2,015.5(899.7)$ & $2,887.6(772.8)$ \\
\hline
\end{tabular}



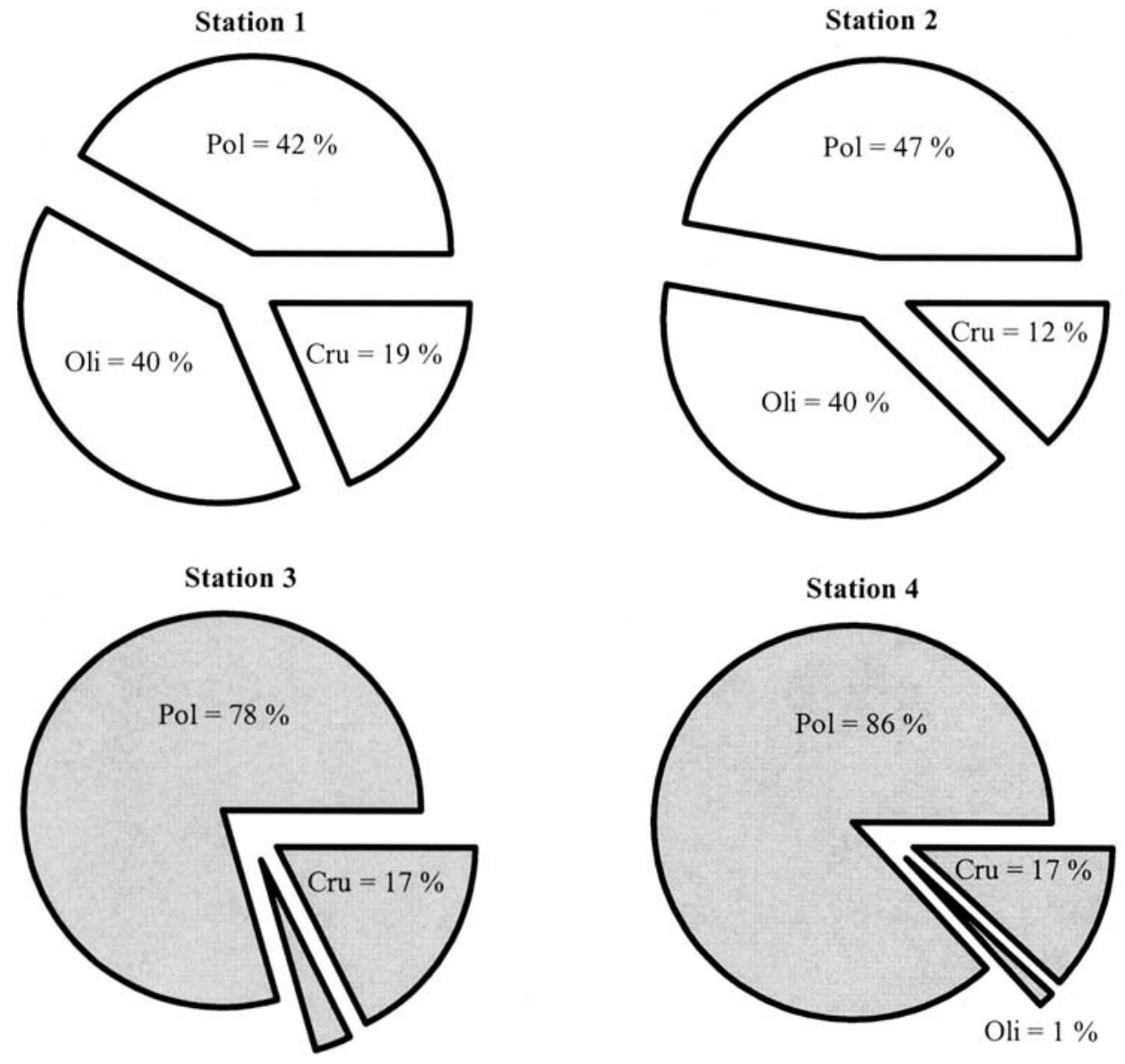

$\mathrm{Oli}=3 \%$

Station 5

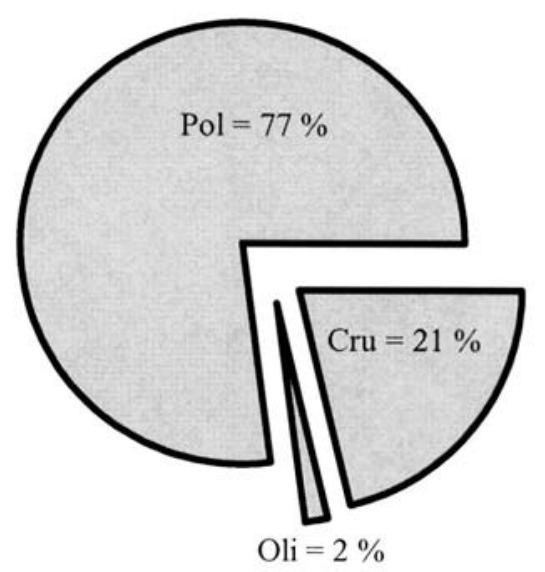

Pol $=$ Polychaeta $\quad$ Oli $=$ Oligochaeta $\quad$ Cru $=$ Crustacea Peracarida

Fig. 3: Abundances in percentages of polychaetes, oligochaetes and peracarid crustaceans at the sampling stations. Stations one and two (white pies) were located on the mussel bed, all the others (grey pies) outside the bed.

Porcentajes de abundancia de poliquetos, oligoquetos y crustáceos peracáridos en las estaciones de muestreo. Las estaciones uno y dos (gráficos circulares blancos) se localizaron en el banco de bivalvos, todas las otras (gráficos circulares grises) fuera del banco. 

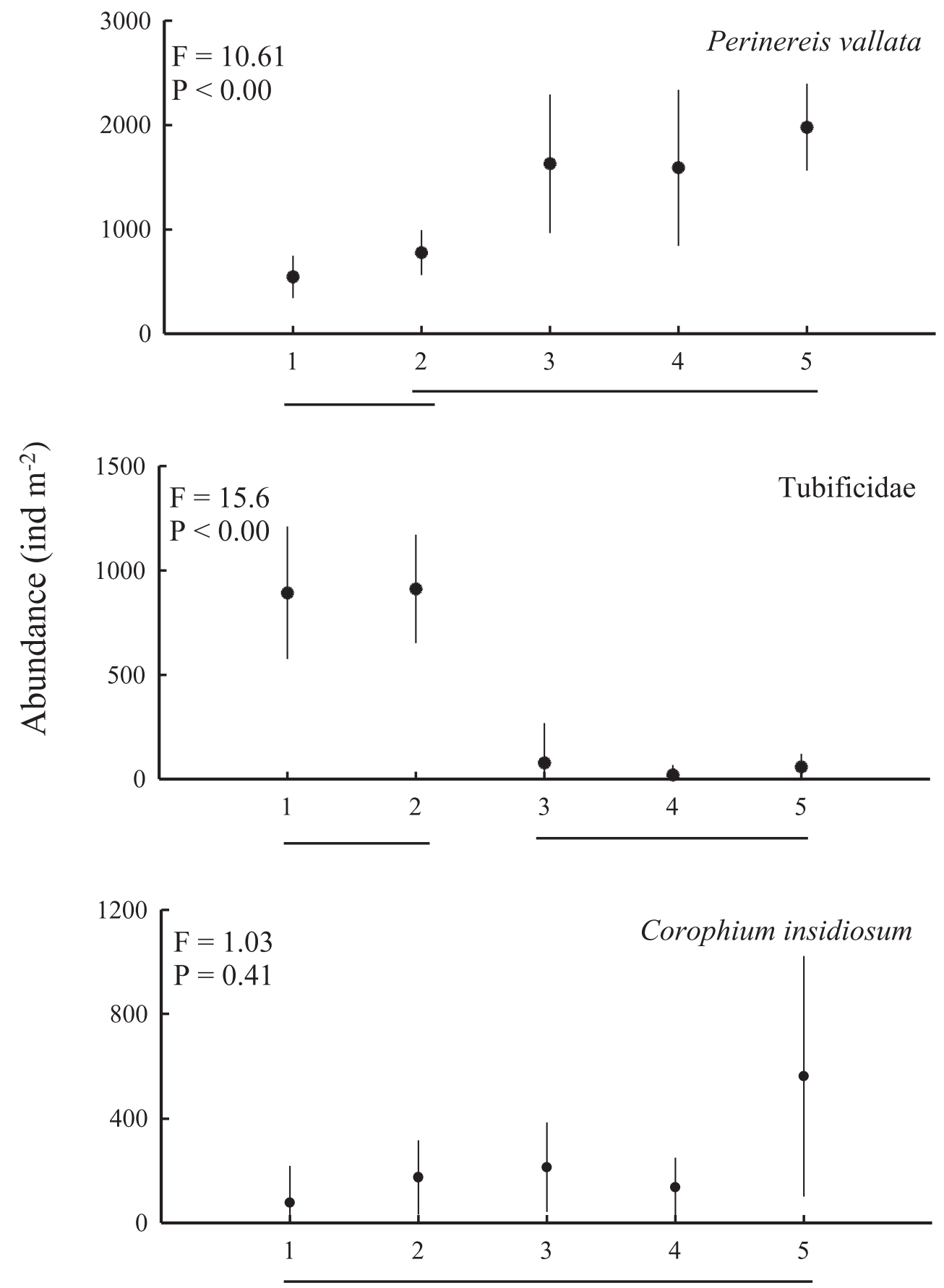

\section{Sampling station}

Fig. 4: Means ( \pm 1 standard deviation) of the abundance of the polychaete Perinereis vallata, an oligochaete species of the family Tubificidae and the amphipod Corophium insidiosum at the sampling stations. Values of $\mathrm{F}$ and $\mathrm{P}$ resulting form ANOVA are given for each comparison. Lines link means not significantly different among each others $(\mathrm{P}>0.05)$ (results of the a-posteriori Tukey HSD test).

Promedios ( \pm 1 desviación estándar) de la abundancia del poliqueto Perinereis vallata, una especie de oligoqueto de la familia Tubificidae y del anfípodo Corophium insidiosum. Se entregan los valores de F y P resultantes de los análisis de varianza de una vía para cada comparación. Las líneas unen promedios que no difieren significativamente entre sí (P > $0,05)$ (resultados de la prueba a posteriori HSD de Tukey). 


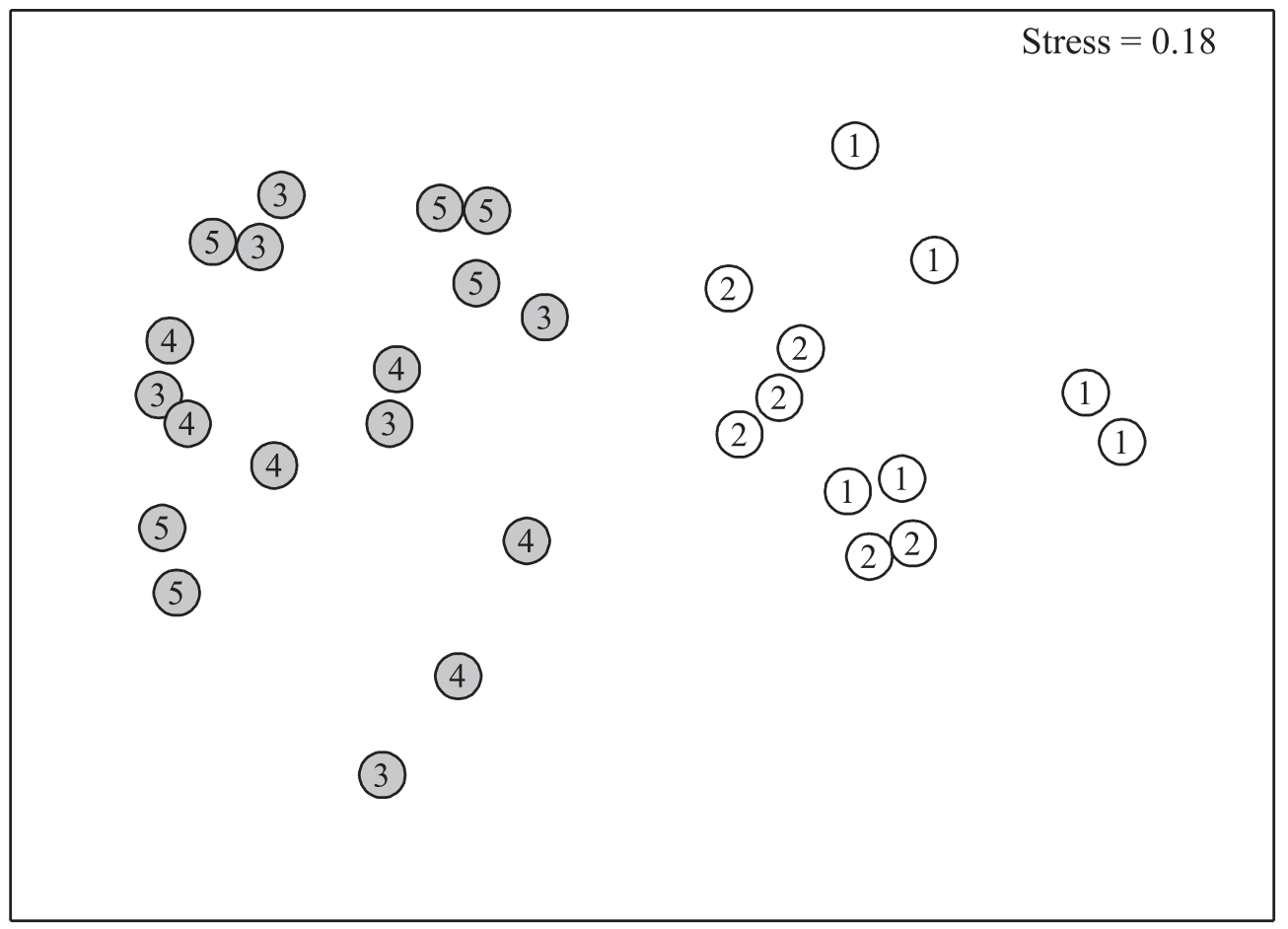

Fig. 5: Graphic display of the non metric multi dimensional scaling (NMMDS) analysis carried out with the macroinfauna data (see Material and Methods for details). The replicates of stations one and two (located in the mussel bed) are represented by white circles, while that of the stations three, four and five (located outside of the bed) are represented by grey circles.

Representación gráfica del análisis de escalamiento multidimensional no métrico (NMMDS) llevado a cabo con los datos de la macroinfauna (ver Materiales y Métodos para detalles). Las réplicas de las estaciones uno y dos (localizadas en el banco de bivalvos) se representan con círculos blancos, mientras que las de las estaciones tres, cuatro y cinco (localizadas fuera del banco) se representan con círculos grises.

TABLE 2

Dissimilarity in percentage among sampling stations: results of SIMPER analysis based on the abundances of the macroinfauna species;

$(*)=$ significant differences $(\mathrm{P}<0.05)$ according the results of the ANOSIM test (see Material and Methods for details)

Disimilitud porcentual entre estaciones de muestreo: resultados del análisis SIMPER basado en las abundancias de las especies de la macroinfauna; $(*)=$ diferencias significativas $(\mathrm{P}<0,05)$ de acuerdo a los resultados de la prueba ANOSIM (ver Materiales y Métodos para detalles)

$\begin{array}{llll}\text { Station } 1 & \text { Station } 2 & \text { Station } 3 & \text { Station } 4\end{array}$

Station 1

Station $2 \quad 38.4$

Station $360.7 * \quad 54.3 *$

Station $4 \quad 62.9 * \quad 53.6 * \quad 31.0$

Station 5

$61.9 *$

$53.3 *$

34.9

35.3
Relationships between macroinfauna and sediment characteristics

We tested, through simple regression analyses, the relationships between number of species, Shannon-Wiener diversity and population abundances of the total macroinfauna with percentages of gravel, sand, mud, biogenic aggregates and total organic matter and mean grain size of sands. Shannon-Wiener diversity values correlated positively and significantly with percentages of biogenic aggregates $(\mathrm{r}=$ $0.471, \mathrm{P}=0.01)$ and mud $(\mathrm{r}=0.400, \mathrm{P}=0.03)$ and negatively and significantly with percentage of sands $(r=-0.424, P=0.02)$. Spatial variability of population abundances and number of species of the macroinfauna did not show any significant correlation with sediment characteristics. 

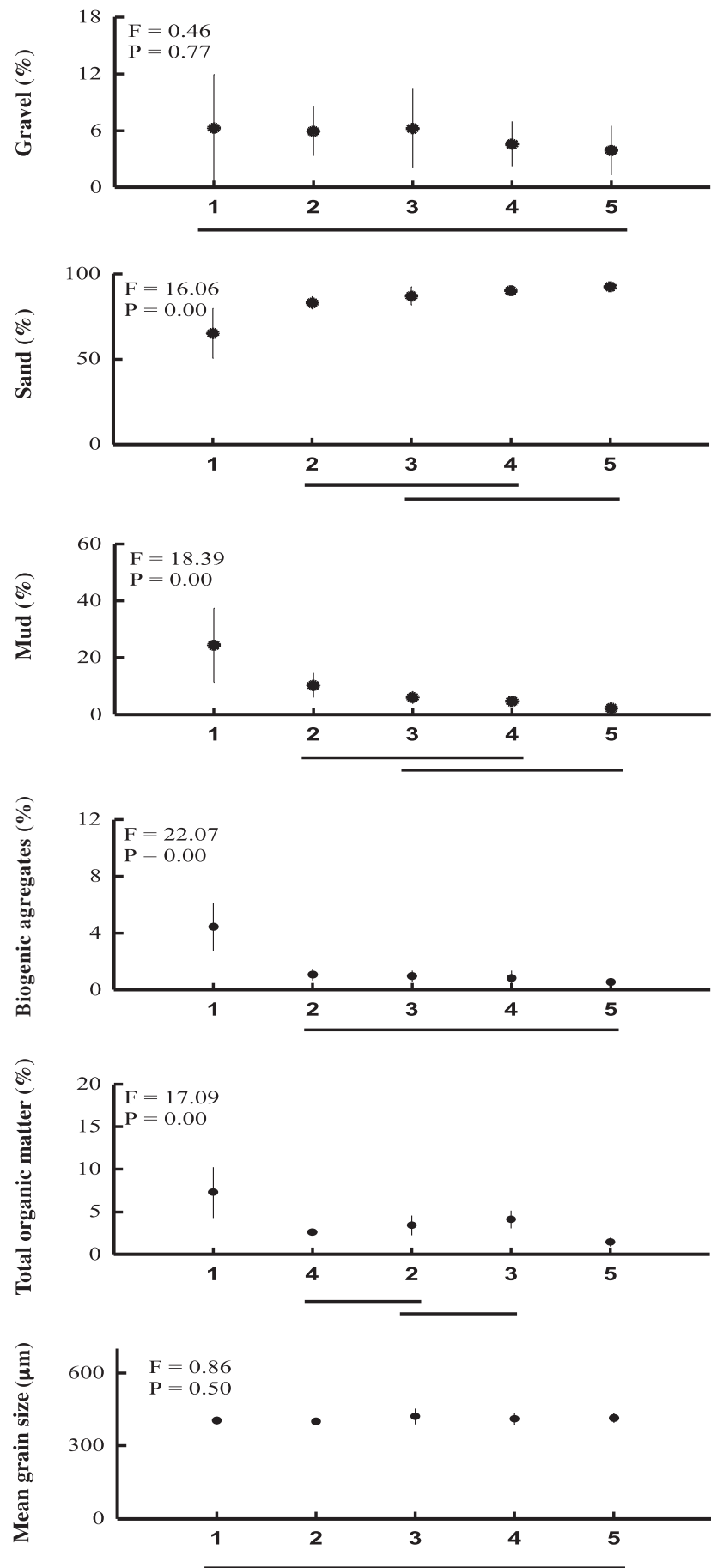

Sampling station

Fig. 6: Means ( \pm 1 standard deviation) of the percentages of gravel, sand, mud, biogenic aggregates and total organic matter in the sediments and mean grain size of sands of the sampling stations. Values of $\mathrm{F}$ and $\mathrm{P}$ resulting form ANOVA are given for each comparison. Lines link means not significantly different among each others $(\mathrm{P}>0.05)$ (results of the a-posteriori Tukey HSD test).

Promedios ( \pm 1 desviación estándar) de los porcentajes de grava, arena, fango, agregados biogénicos y materia orgánica total en los sedimentos y tamaño medio de la fracción arena, de las estaciones de muestreo. Se entregan los valores de F y $\mathrm{P}$ resultantes de los análisis de varianza de una vía para cada comparación. Las líneas unen promedios que no difieren significativamente entre sí $(\mathrm{P}>0,05)$ (resultados de la prueba a posteriori HSD de Tukey). 


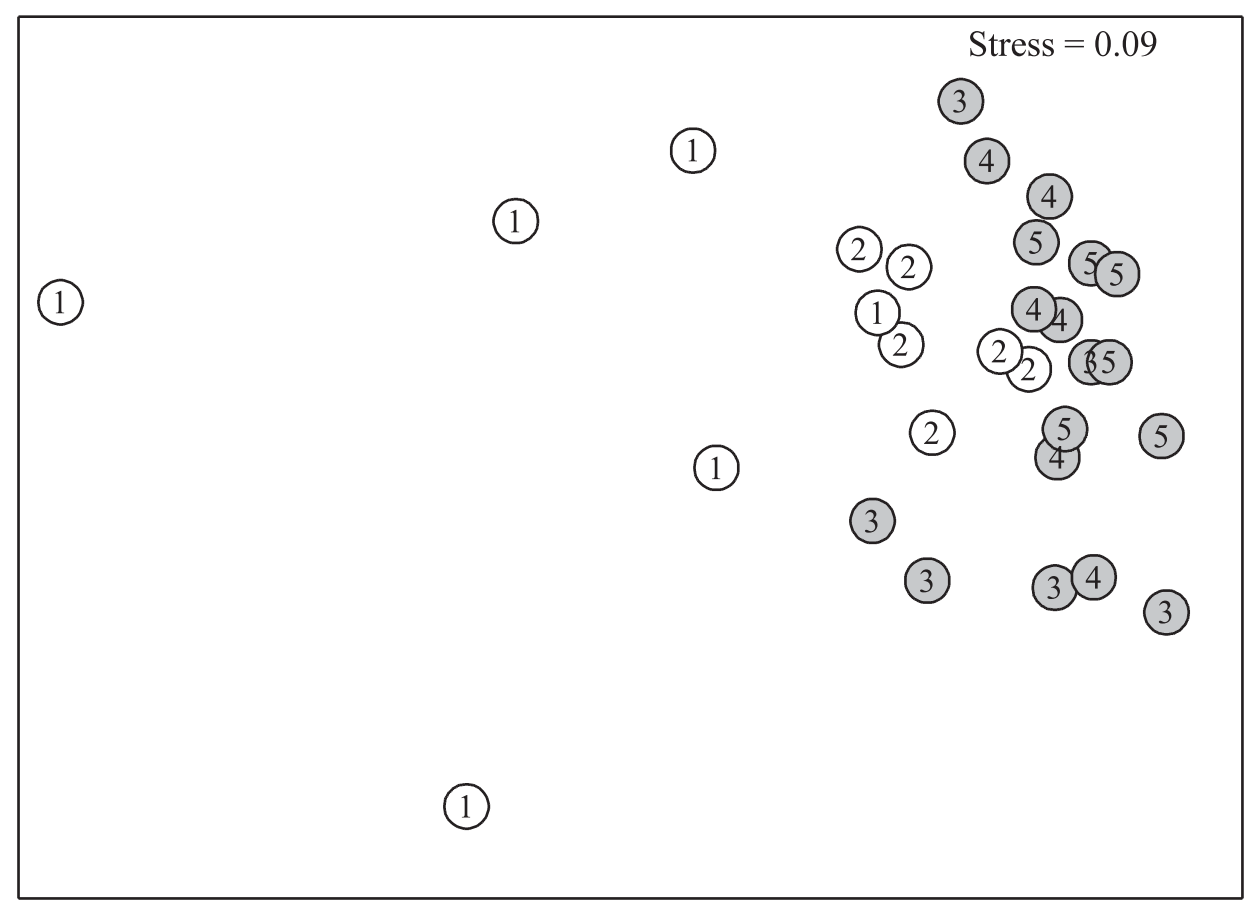

Fig. 7: Graphic display of the Non Metric Multi Dimensional Scaling (NMMDS) analysis carried out with the sediment data (see Material and Methods for details). The replicates of stations one and two (located in the mussel bed) are represented by white circles, while that of the stations three, four and five (located outside of the bed) are represented by grey circles.

Representación gráfica del análisis de escalamiento multi dimensional no métrico (NMMDS) llevado a cabo con los datos sedimentológicos (ver Materiales y Métodos para detalles). Las réplicas de las estaciones uno y dos (localizadas en el banco de bivalvos) se representan con círculos blancos, mientras que las de las estaciones tres, cuatro y cinco (localizadas fuera del banco) se representan con círculos grises.

The results of BIO-ENV routine show that the best fit between the taxonomic composition of the macroinfauna and single sediment variables, was reached with percentages of sand and mud ( $p_{w}=0.410$ and 0.406 , respectively) (Table 5). Fits a little bit higher were found via the combination of percentages of sand and mud $\left(p_{w}=0.431\right)$ and sand, mud and total organic matter percentages $\left(p_{w}=0.415\right)$ (Table $5)$. The results of RELATE analysis showed a significant correlation $(\mathrm{P}<0.05$, Spearman rank correlation) between the biological matrix subjacent to the NMMDS biplot $(\mathrm{P}<0.05)$ (Fig. 5) and the similarity matrix resulting from the sediment data.

\section{DISCUSSION}

The results of this study show that the number of species, Shannon-Wiener diversity and population abundances of the macroinfauna, did not differ significantly between sediments located underneath the mussel bed of Mytilus chilensis and those without mussels. Thus, our results differ from earlier studies that have reported increases or decreases in the species richness and total abundances of the macroinfauna inhabiting sediments located underneath mussel beds (Commito 1987, Commito \& Boncavage 1989, Dittman 1990, Crooks 1998, Crooks \& Khim 1999, Commito \& Dankers 2001, Commito et al. 2005). Nevertheless, the community structure of the macroinfauna underneath the mussel bed studied here was significantly different from that located outside the bed. While the most represented organisms in the sediments underneath the mussel bed were oligochaetes, the polychaetes (primarily the nereid $P$. vallata) were the most represented ones in sediments without mussels. Moreover, three polychaete species and one peracarid crustacean were just collected outside the 
mussel bed and one species of the last taxon, occurred only inside the bed. Based on these results, we conclude that the mussel beds of $M$. chilensis located in sedimentary intertidals of southern Chile do indeed promote some taxa, but also inhibit other organisms.

The complex physical matrix of a mussel bed can modify the water flux above the bottom (e.g., Eckman et al. 1981, Rhoads \& Boyer 1982, Butman et al. 1994, Commito \& Rusignuolo 2000), which in turn may influence deposition of fine particles and organic matter (Crooks \& Khim 1999). Our results agree with that, since the highest percentages of mud particles $(<63 \mu \mathrm{m})$ and total organic matter occurred in the sediments underneath the mussel bed. These sediment characteristics would explain the higher abundances of oligochaetes we found there as compared to bare sediments without mussels. These organisms are known to have high population abundances in fine sediments enriched with organic matter (Hunter \& Arthur 1978, Birtwell $\&$ Arthur 1980), where they use microflora and bacteria, as food (McCall et al. 1979).

The positive relationship between population abundances of oligochaetes and mussel beds has been quite documented for tidal flats around the world. For example, Commito (1987) reported that in the underneath sediments of a mussel bed of Mytilus edulis L. located in an intertidal flat of Maine (USA), the population abundances of the oligochaete Tubificoides benedeni (Udekem) was nearly five times higher than in nearby sediments without mussels. Dittmann (1990) studied the macroinfauna associated to a bed of
Mytilus edulis in the North Sea, finding that oligochaetes were the dominant invertebrates in the sediments underneath the mussel cover. A similar pattern was found for the polychaetes Boccardia sp., a worm similar in size and feeding strategy to that of oligochaetes (Commito \& Dankers 2001) and Capitella sp., a polychaete known to increase in sediments rich in organic matter (e.g., Ragnarsson \& Raffaeli 1999). The above findings stand against one of the core predictions of Woodin (1976), when she described the types of adult-larval interactions that can occur in dense infaunal assemblages like mussel beds; i.e. "no infaunal forms should consistently attain their highest densities among densely packed suspension-feeding bivalves".

Mussel beds remove large quantities of suspended particulate matter from the water column (e.g., Officer et al. 1982, Navarro \& Thompson 1996). It has been also shown that these bivalves are also able to ingest larval stages of other invertebrates, such as polychaetes, gastropods and asteroids (e.g., Cowden et al. 1984, Lehane \& Davenport 2002), a fact to remind that that ingestion would inhibit the settlement of competent larvae inside the beds (Woodin 1976). The significant decrease in the population abundances of the polychaete $P$. vallata $(\geq 90$ $\%$ of the polychaetes collected), towards the stations located inside the mussel bed, could be the result of such kind of adult-larval interaction (sensu Woodin 1976), since this species has free-swimming larvae (HartmannSchröder 1962), prone to be filtered by the mussels or suffocated by their biodeposits (e.g.,

TABLE 3

Sediment characteristics of the sampling stations. The values are percentages (means and standard deviations in parentheses) with exception of mean grain size of sands that are given in microns

Características sedimentológicas de las estaciones de muestreo. Los valores son porcentajes (promedios y desviación estándar en paréntesis) con excepción de los tamaños medios de la arena que se dan en micrones

\begin{tabular}{lcccccc}
\hline Station & Gravel & Sand & Mud & $\begin{array}{c}\text { Biogenic } \\
\text { aggregates }\end{array}$ & $\begin{array}{c}\text { Total organic } \\
\text { matter }\end{array}$ & $\begin{array}{c}\text { Mean grain size } \\
\text { of sands }\end{array}$ \\
\hline Station 1 & $6.24(5.65)$ & $65.00(14.63)$ & $24.35(12.99)$ & $4.42(1.69)$ & $7.25(2.99)$ & $402.6(12.6)$ \\
Station 2 & $5.90(2.62)$ & $82.85(3.56)$ & $10.22(4.36)$ & $1.03(0.41)$ & $3.38(1.14)$ & $398.9(12.7)$ \\
Station 3 & $6.20(4.19)$ & $86.87(5.24)$ & $6.00(2.28)$ & $0.94(0.39)$ & $4.06(1.06)$ & $420.1(32.7)$ \\
Station 4 & $4.56(2,35)$ & $90.00(2.00)$ & $4.66(1.23)$ & $0.79(0.55)$ & $2.57(0.38)$ & $410.0(24.7)$ \\
Staton 5 & $3.88(2,60)$ & $92.30(2.18)$ & $2.20(0.47)$ & $0.51(0.26)$ & $1.39(0.51)$ & $413.1(18.8)$ \\
\hline
\end{tabular}


Bayne et al. 1976, Navarro 1983, Jaramillo et al. 1992, Navarro \& Thompson 1996) and by the passive sedimentation of fine particles, which result in low oxygen conditions (Hunter $\&$ Arthur 1978). On the other hand, the fact that tubificid worms have cocoon from which young organisms hatch (McCall et al. 1979, Barnes 1987), may well explain their high densities in the sediments underneath the mussel bed; in other words, the early life stages of tubificid worms cannot be consumed by the bivalves (Commito 1987).

Independent from the mechanisms throughout which suspension feeder bivalves affect the surrounding macroinfauna, it has been commonly observed that mussel beds do indeed promote the persistence of species without free-swimming larvae (e.g., Commito \& Dankers 2001, Commito et al. 2005). Although our results generally agree with this conclusion (i.e., promotion of tubificid oligochaetes), we did not find a similar pattern for other species lacking free-swimming larvae, like brooding peracarid crustaceans. From the whole number of peracarid species collected (4), just two of them (the isopod Isocladus calcareus (Dana) and the amphipod Hyale sp.) had higher population abundances underneath the mussel bed, another one (the amphipod $C$. insidiosum) had similar abundances inside and outside the bed, while the fourth species (the isopod Exosphaeroma lanceolata (White)) occurred just in bare sediments without mussels. These results suggest that the distribution and population abundances of macroinfaunal species inhabiting sediments underneath a mussel bed can be affected not only by direct mechanisms derivated from that bed, but also throughout the interaction with other species as shown for example by Ragnarsson \& Rafaelli (1999). These authors found that the decreases in population abundances of the polychaete Eteone longa (Fabricius), underneath a bed of M. edulis in the Ythan estuary (UK), was the result of the decrease of its main prey, the polychaete Pygospio elegans Clapàrede. At this time however, we are not able to go deeper in this aspect, due to the general lack of knowledge we have on the natural history of the intertidal macroinfauna inhabiting sedimentary bottoms of the north Patagonic archipelagos of the Chilean coast.

\section{TABLE 4}

Dissimilarity in percentage among sampling stations: results of SIMPER analysis based on the sediment characteristics; $(*)=$ significant differences $(\mathrm{P}<0.05)$ according the results of the ANOSIM test (see Material and Methods for details)

Disimilitud porcentual entre estaciones de muestreo: resultados del análisis SIMPER basado en las

características sedimentológicas; $(*)=$ diferencias significativas $(\mathrm{P}<0,05)$ de acuerdo a los resultados de la prueba ANOSIM (ver Materiales y Métodos para detalles)

\begin{tabular}{lcccc}
\hline Station & Station 1 & Station 2 & Station 3 & Station 4 \\
\hline Station 1 & & & & \\
Station 2 & $7.74^{*}$ & & & \\
Station 3 & $9.36^{*}$ & 4.43 & & \\
Station 4 & $10.25^{*}$ & $4.37^{*}$ & 4.10 & \\
Station 5 & $12.82^{*}$ & $7.14^{*}$ & $6.63^{*}$ & $5.09^{*}$ \\
\hline
\end{tabular}

The different mussel densities studied here (i.e., differences in cover percentages), did not convey significant differences in the underlying macroinfauna, suggesting that a threshold do indeed exists for mussel cover. In other words, our data suggest that above a mussel cover close to $25 \%$, the positive or negative impacts of the mussel bed do not increase with increasing mussel cover. Similar conclusions were reached by Commito \& Boncavage (1989), which after an artificial increase of the natural density of $M$. edulis in an intertidal flat of New England (USA) (from about 2,000 ind $\mathrm{m}^{-2}$ to 4,200 ind $\mathrm{m}^{-2}$ ), did not find significant increases in the population abundances of the oligochaete $T$. benedeni.

In summary, our study shows that the mussel beds of $M$. chilensis located in intertidal sedimentary bottoms of southern Chile, may not only promote or inhibit the presence or some macroinfauna, but also not produce apparent effects on some taxa. Thus, the role of this bivalve as an ecosystem engineer (sensu Jones et al. 1994), and consequently, in the preservation of local faunal diversity, must be taken into account. Further studies would have to also examine the fauna dwelling between the mussels themselves, to gain a better understanding of the role of mussel beds on the surrounding macrofauna. This is of particular importance in a coastal zone heavily harvested and threatened by anthropogenic causes, such as organic enrichment and urban development. 
TABLE 5

Results of the BIO-ENV routine: only the highest correlations between the matrices of biotic and abiotic similarity are given (see Material and Methods for details)

Resultados de la rutina BIO-ENV: solo se entregan las correlaciones más altas entre las matrices de similitud biótica y abiótica (ver Materiales y Métodos para detalles)

\begin{tabular}{clc}
\hline Number of variables & Variable combination & Spearman rank correlation $\left(p_{w}\right)$ \\
\hline 1 & Sand & 0.410 \\
1 & Mud & 0.406 \\
2 & Sand, mud & 0.431 \\
2 & Mud, total organic matter & 0.386 \\
2 & Sand, total organic matter & 0.381 \\
2 & Sand, biogenic aggregates & 0.367 \\
3 & Sand, mud, total organic matter & 0.415 \\
3 & Sand, biogenic aggregates, mud & 0.390 \\
4 & Sand, biogenic aggregates, mud, total organic matter & 0.387 \\
4 & Gravel, sand, mud, total organic matter & 0.368
\end{tabular}

\section{ACKNOWLEDGEMENTS}

We thank Sandra Cifuentes for field assistance and Marcia González for sorting of samples. The final data analyses and manuscript writing benefited from the financial support given to EJ (FONDECYT grant 1030335) to carry on research on tidal flats of southern Chile.

\section{LITERATURE CITED}

ANDERSON F, L BLACK, L MAYER \& L WATLING (1981) A temporal and spatial study of a mud flat texture. Northeastern Geology 3: 184-196.

BARNES R (1987) Invertebrate Zoology. Fifth edition. CBS College Publishing, New York, New York, USA. 893 pp.

BAYNE BL, RJ THOMPSON \& J WIDDOWS (1976) Physiology. In: Bayne BL (Ed) Marine mussels: their ecology and physiology: 121-206. Cambridge University Press, Cambridge, United Kingdom.

BIRTWELL IR \& DR ARTHUR (1980) The ecology of tubificids in the Tames estuary with particular reference to Tubifex costatus (Clapanedi). In: Brinkshurst RO \& DG Cook (eds) Aquatic oligochaete biology: 331-382. Plenum Press, New York, New York, USA.

BUTMAN CA, M FRÉCHETTE, WR GEYER \& VR STARCZAK (1994) Flume experiments on food supply to the blue mussel Mytilus edulis L. as a function of boundary-layer flow. Limnology and Oceanography 39: 1755-1768.

CLARKE KR \& M AINSWORTH (1993) A method of linking multivariate community structure to environmental variables. Marine Ecology Progress Series 92: 205-219.

CLARKE KR \& RM WARWICK (1994) Change in marine communities: An approach to statistical analysis and interpretation. Plymouth Marine Laboratory, Plymouth, United Kingdom. 144 pp.

COMMITO JA (1987) Adult-larval interactions: predictions, mussels and cocoons. Estuarine Coastal and Shelf Science 25: 599-606.

COMMITO JA \& EM BONCAVAGE (1989) Suspensionfeeders and coexisting infauna: an enhancement counterexample. Journal of Experimental Marine Biology and Ecology 125: 33-42.

COMMITO JA \& NM DANKERS (2001) Dynamics of spatial and temporal complexity in European and North American soft-bottom mussel beds. In: Reise $\mathrm{K}$ (ed) Ecological comparisons of sedimentary shores: 39-59. Spring-Verlag, Berlin, Germany.

COMMITO JA \& BR RUSIGNUOLO (2000) Structural complexity in mussel beds: the fractal geometry of surface topography. Journal of Experimental Marine Biology and Ecology 255: 133-152.

COMMITO JA, EA CELANO, HJ CELICO, S COMO \& CP JOHNSON (2005) Mussel matter: postlarval dispersal dynamics altered by a spatially complex ecosystem engineer. Journal of Experimental marine Biology and Ecology 316: 133-147.

COWDEN C, CM YOUNG \& FS CHUA (1984) Differential predation on marine invertebrate larvae by two benthic predators. Marine Ecology Progress Series 14: 145-149.

CROOKS JA (1998) Habitat alteration and communitylevel effects of an exotic mussel, Musculista senhousia. Marine Ecology Progress Series 162: 137-152.

CROOKS AJ (2002) Characterizing ecosystem-level consequences of biological invasions: the role of ecosystem engineers. Oikos 97: 153-166.

CROOKS JA \& HS KHIM (1999) Architectural vs biological effects of a habitat-altering, exotic mussel, Musculista senhousia. Journal of Experimental Marine Biology and Ecology 240: 5375.

DAME RE, D BUSHEK \& TC PRINS (2000) Benthic suspension feeders as determinants of ecosystem 
structure and function in shallow coastal waters. In: Reise K (ed) Ecological comparisons of sedimentary shores: 37-59. Spring-Verlag, Berlin, Germany.

DITTMANN S (1990) Mussel beds-amensalism or ameloration for intertidal fauna? Helgoländer Meeresunters 44: 335-352.

ECKMAN JE, ARM NOWEL \& PA JUMARS (1981) Sediment destabilization by animal tubes. Journal of Marine Research 39: 361-374.

EMERY KO (1938) A simple method of mechanical analysis of sands. Journal of Sedimentary Petrology 8: $105-111$

GUTIÉRREZ JL, CG JONES, DL STRAYER \& OO IRIBANE (2003) Mollusk as ecosystem engineers: the role of shell production in aquatic habitats. Oikos 101: 79-90.

HARTMANN-SCHRÖDER G (1962) Zur Kenntnis der Nereiden Chiles (Polycaheta errantia), mit Bescheribung epitokes Stadien einiger Arten und der Jugendentwicklung von Perinereis vallata (Grube). Zoologischer Anzeiger 168: 27-29.

HUNTER J \& DR ARTHUR (1978) Some aspects of the ecology of Peloscolex benedeni Udekem (Oligochaeta: Tubificidae) in the Thames estuary. Estuarine Coastal Marine Science 6: 197-208.

JARAMILLO E, BERTRÁN C \& A BRAVO (1992) Mussel biodeposition in an estuary in southern Chile. Marine Ecology Progress Series 82: 85-94.

JONES CG, JH LAWTON \& M CHACHAK (1994) Organisms as ecosystem engineers. Oikos 689: 373386.

LEHANE C \& J DAVENPORT (2002) Ingestion of mesozooplankton by three species of bivalve; Mytilus edulis, Cerastoderma edule and Aequipecten opercularis. Journal of Marine Biology Association (United Kingdom) 82: 615-619.

McCALL PL, MJS TEVESZ \& SF SCHWELGIEN (1979) Sediment mixing by Lampsilis radiata siliquoidea (Mollusca) from western Lake Erie. Journal of Great Lakes Research 5: 105-111.

MENGE BA, EL BERLOW, CA BLANCHETTE, SA NAVARRETE \& SA YAMADA (1994) The keystone species concept: variation in interaction strength in a rocky intertidal habitat. Ecological Monographs 64: 249-286.

NAVARRO JM (1983) Oferta alimenticia natural y su efecto sobre los procesos fisiológicos del bivalvo Mytilus chilensis en la bahía de Yaldad, Chiloé (sur de Chile). Memorias de la Asociación Latinoamericana de Acuicultura 5: 175-187.

NAVARRO JM \& RJ THOMPSON (1996) Physiological energetics of the horse mussel Modiolus modiolus in a cold ocean environment. Marine Ecology Progress Series 138: 135-148.

OFFICER CB, TJ SMAYDA \& R MANN (1982) Benthic filter feeding: a natural eutrophication control. Marine Ecology Progress Series 9: 203-210.

PAINE RT \& SA LEVIN (1981) Intertidal landscapes: disturbance and the dynamics of pattern. Ecological Monographs 51: 145-178

PEAKE A \& GP QUINN (1993) Temporal variations in species-area curves for invertebrates in clumps of an intertidal mussel. Ecography 16: 269-277.

PECHINEK JA (1979) Role of encapsulation in invertebrate life histories. American Naturalist 114: 859-870.

RAGNARSSON SA \& D RAFFAELI (1999) Effects of the mussel Mytilus edulis L. on the invertebrate fauna of sediments. Journal of Experimental Marine Biology and Ecology 241: 31-43.

RHOADS DC \& LF BOYER (1982) The effects of marine benthos on physical properties of sediments: a succesional perspective. In: McCall PL \& MJS Tevesz (eds) Animal-sediment relations: The biogenic alteration of sediments: 3-52. Plenum Press, New York, New York, USA.

RICCARDI A, FG WHORISKEY \& JB RASMUSSEN (1997) The role of the zebra mussel (Dreissena polymorpha) in structuring macroinvertebrate communities on hard substrata. Canadian Journal Fisheries Aquatic Science 54: 2596-2608.

SEWARD-THOMPSON B \& J HAILS (1973) An appraisal on the computation of statistical parameters in grain size analysis. Sedimentology 11: 83-98

SOKAL RR \& FJ ROHLF (1995) Biometry: The principles and practice of statistics in biological research. Freeman W.H. Press, New York, New York, USA. $877 \mathrm{pp}$.

SUCHANEK TH (1980) Diversity in natural and artificial mussel bed communities of Mytilus californianus. American Zoology 20: 807

SUCHANEK TH (1985) Mussels and their role in structuring rocky shore communities. In: Moore PG \& R Seed (eds) The ecology of rocky coasts: 70-96. Hodder and Stoughton, Kent, United Kingdom.

TSUCHIYA M \& M NISHIHIRA (1985) Islands of Mytilus as a habitat for small intertidal animals: effect of island size on community structure. Marine Ecology Progress Series 25: 71-81.

TSUCHIYA M \& M NISHIHIRA (1986) Islands of Mytilus edulis as a habitat for small intertidal animals: effects of Mytilus age structure on the species composition of the associated fauna and community organization. Marine Ecology Progress Series 31:171-178

VIVIANI CA (1979) Ecogeografia del litoral chileno. Studies on Neotropical Fauna and Environment 14: 65-123.

WIDDOWS J, MD BRINSLEY, PN SALKELD Y M ELLIOTT (1998) Use de anular flumes to determine the influence of current velocity and bivalves on material flux at the sediment-water interface. Estuaries 21: 552-559.

WOODIN SA (1976) Adult-larval interactions in dense infaunal assemblages: patterns of abundance. Journal of Marine Research 34: 25-41 